Linköping Studies in Science and Technology

Dissertations, No. 1866

\title{
Towards Increased Use of Discrete-Event Simulation for Hospital Resource Planning
}

\author{
Krisjanis Steins
}

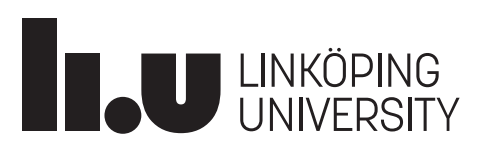

Department of Science and Technology

Linköping University, SE-601 74 Norrköping, Sweden

Norrköping 2017 
Towards Increased Use of Discrete-Event Simulation for Hospital Resource Planning

Krisjanis Steins

Linköping Studies in Science and Technology. Dissertations, No. 1866

Copyright (C) 2017 Krisjanis Steins, unless otherwise noted

ISBN 978-91-7685-488-4

ISSN 0345-7524

Printed by LiU-Tryck, Linköping, Sweden, 2017 


\section{ABSTRACT}

Health care systems in many countries are experiencing a growing demand while their resources remain limited. The discrepancy between demand and capacity creates many problems - long waiting times for treatment, overcrowding in hospital wards, high workload, etc. More efficient delivery of health care services can be achieved by better planning of its resources so that the mismatch between demand and capacity is minimized. Planning health care resources, including hospital resources, is difficult due to system complexity and variability in both resource availability and demand. Discrete-event simulation and other operational research methods can be used for solving planning problems in health care, and have been gaining increased attention from researchers during recent decades. Despite the growing number of academic publications, simulation appears to be less used in health care than in other application areas and only a small proportion of simulation studies is actually implemented.

The aim of this thesis is to contribute to increased use of discrete-event simulation in hospital resource planning. The separate studies regarding intensive care unit capacity planning, operating room allocation strategies and the management of emergency patient flow in a radiology department highlight both the possibilities and the requirements for practical application of discrete-event simulation in hospital resource planning. The studies are described in five papers.

In the first paper, the relationship between intensive care unit (ICU) occupancy and patient outcomes was investigated and the results showed that risk adjusted mortality was higher in the group of patients who were treated during high levels of occupancy. This indicates that appropriate planning of ICU resources is necessary to avoid adverse effects on patient outcomes.

In the second paper, analysis of a relatively simple care chain consisting of two hospital departments - emergency and radiology - revealed a process that was not very well defined and measured. Investigation into data availability uncovered disparate information systems storing incompatible and fragmented data. It suggests that the current degree of process orientation and the current IT 
infrastructure does not enable efficient use of quantitative process analysis and management tools such as simulation.

In the third paper, the value and possibilities of using simulation modelling in hospital resource planning were examined through the development and use of a simulation model for improved operating room time allocation and patient flow in a hospital operating department. The model was initially used for studying overcrowding in a post-anaesthesia care unit. Advanced planning logic implemented in the model enabled evaluation of several different scenarios aiming to improve the utilization of operating room resources. The results showed that it is possible to achieve slightly better and more even resource utilization, as well as provide greater flexibility in scheduling operations.

In the fourth paper, a generic ICU model was developed and validated using data from four different hospital ICUs. The model was adapted and calibrated stepwise in order to identify important parameters and their values to obtain a match between model predictions and actual data. The study showed that in presence of high quality data and well defined process logic it is possible to develop a generic ICU simulation model that could provide accurate decision support for planning critical care resources.

In the fifth paper, a number of factors that can contribute to successful implementation of simulation results in health care were identified. The timing of the simulation study must be right to support a critical decision, the benefit from implementation should clearly outweigh the cost of making the necessary changes and the model should be thoroughly validated to increase the credibility of the results. Staff involvement in simulation modelling activities, availability of good quality data, as well as proper incentives to improve the system contribute to implementation as well. These findings can help in establishing the conditions for successful implementation in future applications of simulation modelling in health care. 


\section{SAMMANFATTNING}

Hälso- och sjukvårdssystemen i många länder möter en växande efterfrågan samtidigt som resurserna är begränsade. När efterfrågan överstiger kapaciteten skapas många problem, bland annat långa väntetider för behandling, överbeläggningar i sjukhusavdelningar och hög arbetsbelastning för personalen. En effektivare sjukvård kan uppnås genom bättre planering av resurserna, så att obalansen mellan efterfrågan och kapacitet minimeras. Planering av hälso- och sjukvårdsresurser, inklusive sjukhusresurser, är svårt på grund av systemkomplexitet och variation i både resurstillgänglighet och efterfrågan. Simulering och andra operationsanalytiska metoder som används för att lösa planeringsproblem inom tillverkning, logistik och andra områden, kan med fördel användas också inom sjukvården och har fått ökad uppmärksamhet av forskare under de senaste årtiondena. Trots det växande antalet akademiska publikationer verkar simulering användas betydligt mindre inom sjukvården än $i$ andra tillämpningsområden och endast en liten del av resultaten omsätts i praktiken.

Syftet med denna avhandling är att bidra till ökad användning av simulering vid planering av sjukhusresurser. De separata studierna i avhandlingen behandlar kapacitetsdimensionering av intensivvård, allokering av operationssalsresurser samt hantering av akutpatientflödet på en röntgenavdelning, och lyfter därigenom fram både möjligheterna och kraven för praktisk tillämpning av diskret händelsesstyrd simulering för planering av sjukhusresurser.

Intensivvårdsavdelningar anses vara bland de dyraste resurserna på ett sjukhus. Det är därför ekonomiskt önskvärt att ha en hög utnyttjandegrad av en sådan resurs. Samtidigt är det viktigt att alltid ha utrymme för kritiskt sjuka patienter. I en studie där förhållandet mellan beläggningen på intensivvårdsavdelningar och patientutfall undersöktes visade resultaten att riskjusterad dödlighet var högre för patienter som behandlades när beläggningen på avdelningen var hög, vilket understryker att bra planering av intensivvårdsresurser är mycket viktigt.

Hög grad av processorientering och tillgång till data som möjliggör undersökning av patientflödet över gränserna av sjukhusets organisatoriska och funktionella enheter är exempel på förutsättningar för användning av simulering för hela 
vårdkedjor. En analys av en relativt enkel vårdkedja bestående av två sjukhusavdelningar avslöjade dock en process som inte var särskilt väldefinierad, och där olika informationssystem lagrade inkompatibla och fragmenterade data. Avsaknaden av processorientering och den befintliga IT-infrastrukturen är hinder för effektiv användning av kvantitativa processanalysverktyg som simulering.

Värdet av att utnyttja simulering och modellering för planering av sjukhusresurser användes vidare för att hitta en bättre och jämnare fördelning av operationssalsresurser. Modellen användes för att undersöka ett antal scenarier och resultatet visade att det är möjligt att uppnå ett jämnare utnyttjande av operationssalar och en större flexibilitet vid schemaläggning av operationer.

Generiska simuleringsmodeller, som med hjälp av ett antal parameterinställningar kan omvandlas till en ny modell av en given sjukhusenhet, skulle sannolikt öka användningen av simulering. Dock kan det vara svårt att visa hur dessa modeller avbildar varje specifik enhet på ett tillräckligt trovärdigt sätt. En generisk modell för kapacitetsdimensionering av intensivvårdsavdelningar har utvecklats och validerats med hjälp av data från fyra olika sjukhus. Studien visade att när data är av hög kvalitet och processlogiken är väldefinierad är det möjligt att utveckla en sådan generisk simuleringsmodell som kan ge beslutsstöd vid planering av intensivvårdsresurser.

Flera litteraturundersökningar har visat att endast en liten del av publicerade simuleringsstudier inom sjukvården har implementerats. Genom att studera ett flerårigt simuleringsprojekt identifierades ett antal faktorer som kan bidra till att simuleringsresultat faktiskt används för att förändra verksamheten. Tidpunkten för simuleringsstudien måste vara välanpassad för att stödja ett kritiskt beslut, fördelar med förändringen bör tydligt överväga kostnaden för att genomföra den och modellen bör grundligt valideras för att öka resultatens trovärdighet. Personalens engagemang i modelleringsaktiviteter, tillgång till data av god kvalitet samt lämpliga incitament för att förbättra systemet bidrar också till genomförandet. Resultaten kan hjälpa till att skapa förutsättningar för framgångsrik framtida användning av simulering vid planering av sjukhusresurser. 


\section{LIST OF PAPERS}

I. Steins, K., Holmberg, M., \& Walther, S. (2017). Does high intensive care unit occupancy have adverse effects on patient outcomes? An observational multicentre study of the relationship between occupancy and mortality. Working paper.

II. Fryk, P., \& Steins, K. (2010). A modern process perspective, process mapping, and simulation in health care: Opportunities and IT infrastructural needs. In Proceedings of 2010 IEEE Workshop on Health Care Management (WHCM), Venice, Italy, Feb 18-20 2010

III. Steins, K., Persson, F., \& Holmer, M. (2010). Increasing utilization in a hospital operating department using simulation modeling. Simulation, 86(89), 463-480.

IV. Steins, K., \& Walther, S. M. (2013). A generic simulation model for planning critical care resource requirements. Anaesthesia, 68(11), 1148-1155.

V. Steins, K., \& Persson, F. (2015). Identifying factors for successful implementation of simulation modeling in healthcare. International Journal of Privacy and Health Information Management, 3(1), 1-19. 



\section{ACKNOWLEDGEMENTS}

It has been a long journey, learning a great many things - about simulation, statistics, health care and resource planning in hospital units; about doing research, writing research papers and presenting and explaining my work to different audiences. Many people have helped me and supported me during this journey, and I am deeply grateful to all of you!

First of all I would like to thank my supervisors - Jan Lundgren, Fredrik Persson and Sten Walther, for their guidance, feedback and encouragement during the entire research process and the writing of this thesis. Without your help it simply would not have been possible for me to come this far and learn so much.

Also, I would like to extend my sincere thanks to all of the other co-authors of included papers and all those who made each of the studies possible: Martin Holmberg from Vrinnevi Hospital, Pontus Fryk and staff at the emergency and radiology departments of Danderyd University Hospital; Swedish Intensive Care Registry and PASIVA-group, Region Skåne; Martin Holmer and others from Ryhov County Hospital; Qulturum (Center for Learning and Innovation in Healthcare) for the initial support at Ryhov County Hospital.

Additionally, I would like to thank all my colleagues at the KTS - Division of Communication and Transport Systems, Department of Science and Technology for inspiring discussions and a working environment that I have enjoyed very much.

Parts of this research have been supported by Medical Research Council of Southeast Sweden (FORSS) and Institute for Management of Innovation and Technology (IMIT), for which I am very thankful.

Last but not least, I would like to thank my friends, family, and especially you Agnese - for all your unfailing support during these years!

Krisjanis Steins

Linköping, July 2017 



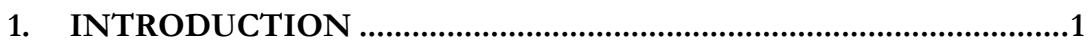

2. HOSPITAL RESOURCE PLANNING ........................................ 5

3. SIMULATION MODELLING AS AN OPERATIONAL RESEARCH METHOD 8

4. SIMULATION IN HEALTH CARE .................................................14

5. RESEARCH CONTRIBUTIONS............................................... 18

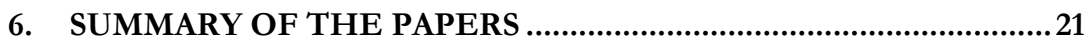

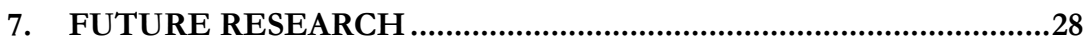

REFERENCES ...................................................................29

PAPER I. DOES HIGH INTENSIVE CARE UNIT OCCUPANCY HAVE ADVERSE EFFECTS ON PATIENT OUTCOMES? AN OBSERVATIONAL MULTICENTRE STUDY OF THE RELATIONSHIP BETWEEN OCCUPANCY AND MORTALITY. .35

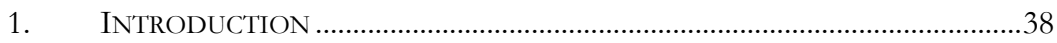

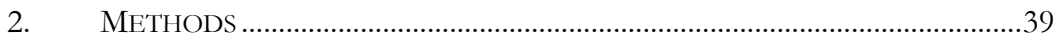

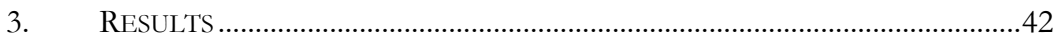

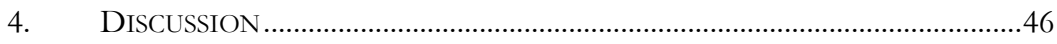

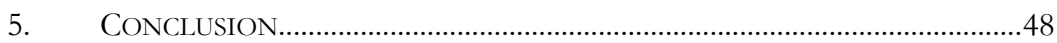

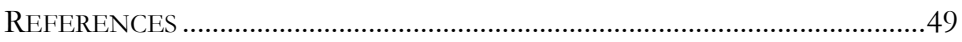

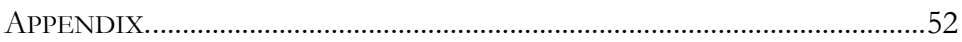

PAPER II. A MODERN PROCESS PERSPECTIVE, PROCESS MAPPING, AND SIMULATION IN HEALTH CARE. OPPORTUNITIES AND IT INFRASTRUCTURAL NEEDS.......................................59

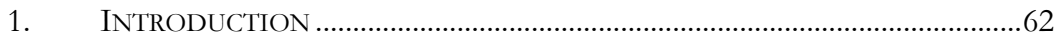

2. Theory - Digitization And Simulation in Health Care................63

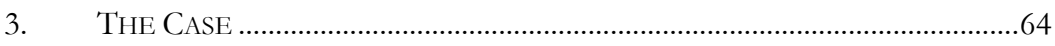

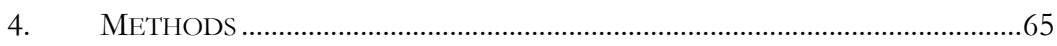




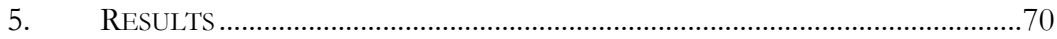

6. DISCUSSION AND CONCLUSIONS …………............................................. 72

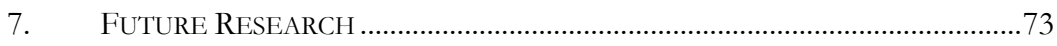

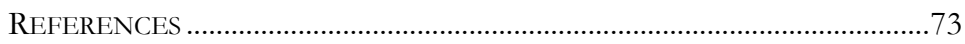

PAPER III. INCREASING UTILIZATION IN A HOSPITAL OPERATING

DEPARTMENT USING SIMULATION MODELING ....................77

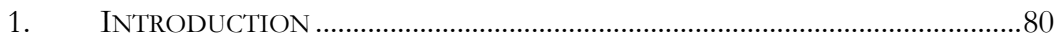

2. OVERVIEW: DEPARTMENT OF OPERATIONS AND INTENSIVE CARE .......82

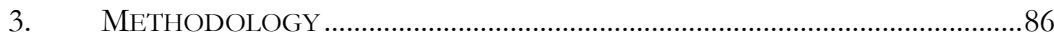

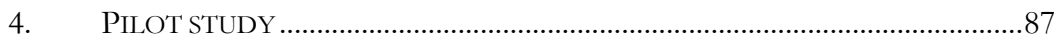

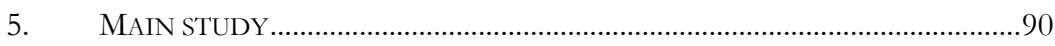

6. CONCLUSIONS AND DISCUSSION …………………....................................... 102

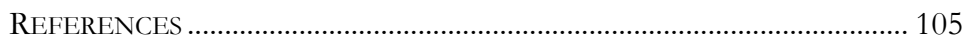

PAPER IV. A GENERIC SIMULATION MODEL FOR PLANNING

CRITICAL CARE RESOURCE REQUIREMENTS........................109

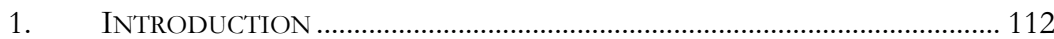

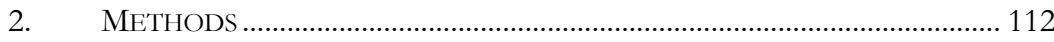

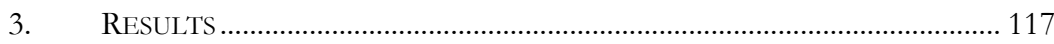

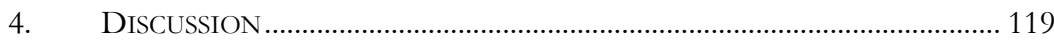

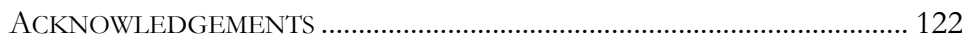

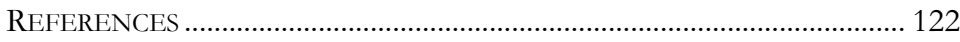

APPENDIX S1. DETAILED DESCRIPTION OF MODEL DEVELOPMENT. .. 124

PAPER V. IDENTIFYING FACTORS FOR SUCCESSFUL

IMPLEMENTATION OF SIMULATION MODELING IN

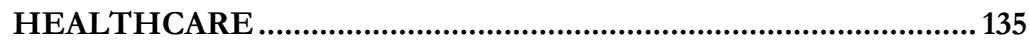

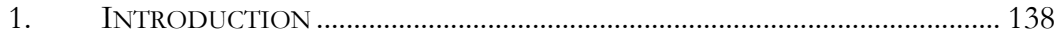

2. IMPLEMENTATION OF HEALTHCARE SIMULATION ................................... 139

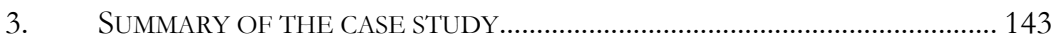

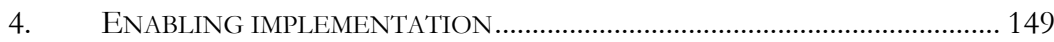

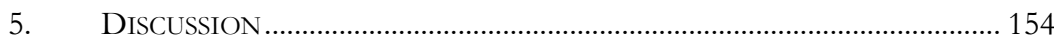

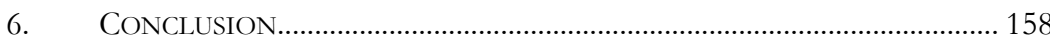

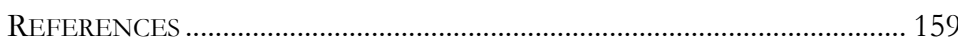




\section{INTRODUCTION}

One of the main challenges for the health care sector in many developed countries today, and especially in the future, will be meeting the ever increasing demand for health services while at the same time trying to control the costs of delivering these services. The total volume of delivered services is increasing mainly due to an ageing population with increased amounts of chronically ill patients and patients having multiple diseases. There is also a demand for a higher quality of the health care as patients demand better services in all aspects of health care, not just medical outcomes. New technologies and treatments have improved health care but not necessarily made it less expensive. On the contrary, costs of health care in many developed countries have been steadily increasing in the past, both in amounts per capita and in their relative share of the country's GDP. In Sweden the total health expenditure has grown from 7.3\% of GDP in 1995 to $11.1 \%$ in 2015 (OECD, 2017a). At the same time, the number of acute care hospital beds per capita has decreased by more than 40\% between 1995 and 2014 (OECD, 2017b), while the number of doctors and nurses has increased during the same period both in absolute figures and per capita (OECD, 2017c; OECD, 2017d). In a report on future trends in health care financing, Stockholm city council has calculated that in 2025 the costs will exceed available funding by somewhere between $17 \%$ in an optimistic scenario and 33\% in a pessimistic scenario (Stockholms läns landsting, 2009). This financial gap can be closed by working in three directions - increasing spending on health care, managing the demand, or providing more health care for the money spent (Stockholms läns landsting, 2009). Examples of the work that can be done in the third direction include improved care processes and improved allocation of resources that match the demand.

In a European comparison Sweden is consistently ranked among the best countries when it comes to medical outcomes, but is found at the very bottom of the list of 35 countries when it comes to waiting times for treatment (Björnberg, 2017). Accessibility problems might be considered as an adverse effect of trying to control the costs but the data shows virtually no correlation between accessibility and health care expenditure per capita among European countries (Björnberg, 2017). Waiting times do not just affect the patient but can generate more work for the health care 
system as patient's condition might get worse and require more effort later, thus increasing the load on the system and probably further increasing average waiting times.

The challenge is thus not just making health care better from a medical point of view, i.e. developing better treatments for patients, but also on making the delivery of health care services more efficient. Better planning could help health care sector meet this challenge, nonetheless it is difficult not only because of the increasing gap in supply and demand, but also as a result of system complexity and variation.

Hospitals, a central part of the health care system, are also facing the same challenges as the health care system in general. In the pursuit for lower costs of delivering health care, hospitals have often been subject to downsizing, reorganizing, and other changes (Green, 2004), where the main goal usually is to bring the system under financial control, and to a much lesser extent to put the patient needs first. Planning of hospital resources could therefore potentially benefit from tools and methods which have been successfully applied in other industries and service organizations, and have helped improve the planning and efficient use of resources while maintaining high quality of the delivered service or product.

Simulation modelling and analysis has been used for problem solving, prediction or analysis in many areas, e.g. in manufacturing, construction engineering, logistics and transportation, computer systems and network design, military applications, and health care (Banks et al., 2010; Pidd, 2003). Simulation, along with other operational research methods, is therefore a good example of the tools and methods used for resource planning mentioned in the previous paragraph. Operational research has been applied in health care since at least 1950s (Royston, 2009), i.e. almost since the beginnings of operational research as a civil discipline. Recently, however, there has been a growth of interest and applications of operational research and simulation in health care, with the number of publications increasing significantly after 1990 (Brailsford et al., 2009).

There are several different types of computer-based simulation: Discrete-event simulation, System dynamics, Monte Carlo simulation and Agent-based simulation. This thesis considers discrete-event simulation (DES), which is the most used simulation method in health care (Mielczarek \& Uziałko-Mydlikowska, 2012). DES implies the modelling of a system as it evolves over time by a representation in which system state variables change instantaneously at separate points of time (Law \& Kelton, 2000). At the heart of every DES model is a future event calendar and a 
set of rules that describe how both the system itself and all statistical variables must be updated for every type of event that can occur in the model. Discrete-event simulation models are dynamic, discrete and (for the most part) stochastic.

Discrete-event simulation models provide a risk-free environment for testing ideas, new policies, decision rules etc. They can handle dynamic and complex systems that involve uncertainty, but at the same time are easy to use and understand. Simulation experiments can be easily repeated and are often less costly than experiments in the real system (Robinson, 2004). Among the disadvantages of simulation are the need for special training to be able to build models and difficulty in interpreting the results from stochastic simulations (Banks et al., 2010). Also, simulation modelling can be quite time consuming, expensive and require large amounts of data (Robinson, 2004).

Simulation, when applied in the health care environment, faces also some specific modelling challenges - e.g. capturing the behaviour of people (both patients and health care professionals) who play a central role in the system, lack of data on operational aspects of health care, resources that cannot be easily substituted (e.g. doctors and nurses), and dependencies in patient arrivals (Roberts, 2011). Simulation appears to be less used in health care than in other application areas. In addition, there is little evidence on how the results of simulations are actually implemented (Fone et al., 2003) and what the value of using simulation in health care really is.

\section{The overall aim of this thesis is to contribute to an increased use of discrete- event simulation in hospital resource planning.}

In order to achieve the overall aim the current state and challenges for health care simulation are briefly described in Chapter 4 and then some of them are addressed and investigated in more detail in separate studies, described in the five papers included in this thesis.

Papers I and II investigate the need for a better planning of hospital resources and the requirements for application of discrete-event simulation as a capacity planning tool. Papers III and IV investigate the modelling possibilities, developing specific and generic models, and finally Paper $\mathrm{V}$ studies factors influencing the implementation of the simulation results.

The next three chapters describe the research context in more detail. Chapter 2 introduces the application area for the discrete-event simulation, namely hospital resource planning. Chapter 3 describes discrete-event simulation as an operational 
research method, and Chapter 4 describes the health care simulation specifically. Chapter 5 summarizes the main contributions of this thesis, followed by Chapter 6 consisting of the summaries of included papers. Finally, in Chapter 7, an outline for future research is described. 


\section{HOSPITAL RESOURCE PLANNING}

Keeping costs under control, maintaining excellent outcomes and at the same time improving access and minimizing waiting times is a challenging task for health care policy makers and professionals. In solving this task there is a growing need for methods that can help making better decisions in planning, managing and improving health care. According to Brandeau et al. (2004) the decisions to be made can be grouped in two broad areas:

1. Health care planning and organizing which deals with economics and structure of health care systems as well as other public policy issues.

2. Health care delivery which includes both clinical practice and operations management for health care delivery.

Operations management is responsible for making health care delivery both effective (positive health outcomes and patient satisfaction) and efficient (minimizing resource use). These two goals can be in potential conflict with each other as, for instance, improving health outcomes might also mean increased use or resources (Vissers \& Beech, 2005a). The range of issues that operations management deals with spans from strategic decisions on which services are delivered to facility planning and design, to scheduling of individual patients.

Hans et al. (2012) propose a framework for health care planning and control which consists of four managerial areas (medical planning, resource capacity planning, materials planning and financial planning) and four hierarchical levels (strategic, tactical, offline operational and online operational).

Hulshof et al. (2012) provide a classification of resource capacity planning decisions in health care using framework developed by Hans et al. (2012), and grouping planning decisions according to different services in health care - ambulatory care services, emergency care services, surgical care services, inpatient care services, home care services and residential care services. The first four groups of services are often provided in a hospital.

Capacity of the hospital is defined (in simple terms) as its ability to deliver health care services of certain quality to a certain amount of patients over a certain period 
of time. This capacity is created by planning and organizing the hospital's resources, such as staff (doctors, nurses, etc.), facilities and equipment (Källum, 2008). The mismatch between capacity and demand can arise both because of the inherent variation in the patient flow and also because of inadequate resource planning. According to Hall et al. (2006), successful work in reducing delays depends on collaboration between administrative and clinical processes, ability to see health care as a system and find bottlenecks and system failures in patient flows.

In addition to the already mentioned issues of increased demand, rising costs and limited capacity, Williams (2006) mentions limits in technology and informatics as well as lack in industrial engineering tools and methods as key drivers to hospital capacity problems. It is suggested that one of the reasons for delays in health care delivery is inadequate hospital resource planning, which in turn can be explained by historical functional unit orientation, with misaligned capacities that do not necessarily match demand (Kosnik, 2006; Källum, 2008).

Vissers and Beech (2005b) propose a logistic approach for planning and managing hospital resources and distinguish between unit logistics, chain logistics and network logistics, as described below. A unit in a hospital is typically a department that has a well-defined function and has resources allocated to it to carry out its function. For instance, the operating department's primary function is to carry out surgical operations and its resources include operating rooms, staff and equipment. Other examples of units are the radiology department and the intensive care unit. Unit logistics focuses on planning issues in a single unit and can be used for capacity management and efficiency analysis of the unit (Vissers and Beech, 2005b). A typical goal of the unit logistics approach to planning would be to increase resource utilization and throughput of the unit. The disadvantage of the unit logistics approach is that it more or less ignores the fact that both the unit itself and its resources are a part of a longer process or patient flow, and improved performance in one unit can lead to problems elsewhere in the flow. In defence of the unit logistics approach it can be said that if a unit can be identified as a bottleneck or constraint in the overall flow then it might be worthwhile to make sure that this unit operates at its near optimal capacity (compare to Theory of Constraints (Goldratt \& Cox, 2004)). In the chain logistics approach, according to Vissers and Beech (2005b), a chain is defined as a sequence of activities that is required to deliver a particular health care service to the patient. As such it can involve several units that need to coordinate their efforts in order to deliver the service efficiently. The chain logistics approach focuses on the service level and typical performance measures would include total time to deliver a service, waiting times, value-added times, etc. The advantage of the chain logistics approach is obvious from the patient 
flow perspective but the disadvantage is that it often cannot measure resource use properly, as resources are still allocated to functional units, which can be involved in several chains simultaneously. The network logistics approach (Vissers \& Beech, 2005b) combines both unit and chain approaches. This approach makes it possible to evaluate the trade-off between service level and resource utilization, and ideally it should include all or as many units and chains as possible in a hospital. Modelling and analysis become very complex and therefore applications of the network logistics approach are rare.

Having a high resource utilization and providing immediate access to health care services are two goals that often are in conflict with each other. The difficulty for hospital resource planning lies in finding the right balance between utilization and accessibility. In this thesis, the main focus is on hospital units, namely the radiology department, the operating department and the intensive care unit. Operation rooms and intensive care units are examples of expensive hospital resources where high utilization is desirable from an economic point of view, but could hypothetically lead to adverse effects for patients. According to the terminology by Vissers and Beech (2005b), a unit logistics approach is taken in all studies but one, where a chain logistics approach is used to investigate a simple chain consisting of emergency department and radiology department. Using the framework by Hans et al. (2012), the thesis focuses on one managerial area - resource capacity planning, and two hierarchical levels of planning - strategic (capacity dimensioning) and tactical (block planning). 


\section{SIMULATION MODELLING AS AN OPERATIONAL RESEARCH METHOD}

Simulation modelling is one of the methods used in operational research, which aims at solving complex real world problems using a scientific approach. The four main advantages of simulation over alternative analysis methods are the stronger ability to: i) deal with uncertainty, ii) handle complex systems without unnecessary oversimplifications, iii) provide decision support with appropriate level of detail, and iv) visually communicate the proposed solutions. A detailed description of the simulation methodology, as applied in this thesis, is presented below and consists of the following steps:

- Formulation of the objectives

- Model design

- Data collection and analysis

- Model translation

- Verification and validation

- Experimentation

- Analysis of the results

- Implementation

The description is largely based on the simulation study steps given by Kelton et al. (2015) and Banks et al. (2010). It must be noted that a simulation project does not consist of a simple sequence of activities as described below. The different steps must often be revisited as simulation modelling is an iterative process.

Formulation of the objectives. Simulation is often seen as a problem-solving method. The first step in such a simulation project should therefore be to specify the problem to be solved, although sometimes the real problem itself becomes clear only during or after the simulation. From the problem statement one should establish objectives for the whole simulation study (Banks et al., 2010). This includes what questions the simulation model should answer. If the simulation model is intended to evaluate certain alternatives, these alternatives must be outlined and the criteria for their evaluation established by clearly defining performance measures and their target values. After the objectives are specified, 
one must determine if simulation is the appropriate tool and if it is the best alternative among other possibilities. Even if there are simpler ways of finding solutions (e.g. using spreadsheets) the advantages and added value of using simulation should be taken into consideration.

Model design. Here the modeller first makes a conceptual model deciding on the scope and desired level of detail (McHaney, 1991). The flow of entities is often described by a process diagram and the rules and logic governing the flow are captured and documented. The tasks of conceptual modelling - deciding on how to simplify the reality, what to include in the model and how to choose the right level of detail might be some of the most difficult tasks in simulation modelling. It takes skills which are hard to learn in a classroom, and is by some authors considered more an art or craft than science (Banks et al., 2010). The modelling process should begin with a simple model and then, only if found necessary, more detail should be added (Banks et al., 2010).

Data collection and analysis. This step is often interconnected with the model design and both are run in parallel. All model inputs are identified during this stage and relevant data about the system under study is collected according to the model scope and level of detail specified in the previous step. Data is usually gathered by querying databases, conducting interviews, examination of the existing documentation and direct observations and measurements. Data that is collected from databases or other sources must be carefully analysed in order to discover and eliminate possible data errors (errors made while entering data into databases, biased data, missing values, etc.). A lot can be learned about the modelled system just through data analysis. Also, if data describing some of the parameters includes variability or randomness, a careful selection of appropriate probability distributions must be made. Ignoring the randomness can lead to incorrect model behaviour (Kelton et al., 2015), but this could also happen if the randomness is not modelled correctly. The simplest case of modelling randomness is when random variables can be assumed independent and identically distributed (IID). If dependencies in data are discovered during data analysis or model validation then appropriate measures must be taken to include such dependencies in the model.

Model translation. During this step a working simulation model (essentially, a computer program) is created using general-purpose programming language or special simulation software - a simulation language or high-level simulator. The conceptual model must be translated to a specific language or environment, which often restricts the modeller to the constructs that are built into that particular software. Therefore it is not always possible to smoothly transform the logical 
model to a computer model. The actual programming techniques depend very much on the language chosen. Usually, general-purpose languages require more time and effort for model building compared to simulation languages and high-level simulators.

Verification and validation. In simulation a distinction is often made between two types of model tests - verification and validation. Verification is the process of determining whether the simulation model performs as the model builder intended it to do. The model builder checks if the transformation from conceptual model to computer model is accurate by using debugging tools provided in the model development environment, examining both the internal logic of the model as well as the output and animation of the model. Validation is the process of determining whether the simulation model is an accurate representation of the system under study, given the purpose of the study. Validation can be performed by using a number of techniques. These include establishing face validity, comparing the output of a simulation model with historical data, thorough examination of model assumptions, extreme condition tests, sensitivity analysis, etc. (Sargent, 2007). Verification and validation is performed to prevent the occurrence of three major types of errors in simulation projects as defined by Balci (1998) - error of rejecting a valid model (Type I error), error of accepting an invalid model (Type II error) and error of solving the wrong problem (Type III error). Complete model validation is impossible and the model should not be judged as either absolutely correct or absolutely incorrect (Balci, 1998). Instead, the testing is done until there is sufficient confidence that the model produces acceptably accurate results.

Experimentation. This step involves designing and conducting experiments in order to fulfil the objectives of the study. Design of experiments (DOE) involves selecting the alternatives to be simulated and if the number of alternatives is large (many combinations of input parameter values) then statistical DOE techniques can be applied. Experimental setup also involves deciding on initial state conditions for the model, length of warm-up period, length of simulation run, and number of replications (Banks et al., 2010). It is recommended to consider experimental alternatives already during the model design, since it will to a large extent determine the model outputs. On the other hand, new experimental ideas are often generated during the stages of experimentation and analysis, which once more emphasizes the iterative nature of simulation modelling and analysis.

Analysis of the results. Most of the discrete-event simulation models are stochastic. Stochastic simulations, apart from having random input, produce output that is random too (Kelton et al., 2015). Because of this, statistical techniques are 
used for output analysis. Average values across a number of replications as well as confidence intervals are typically calculated for all performance measures. The model is usually run for a sufficient number of replications in order to have confidence intervals that are narrow enough. Simulation modelling often involves more than just evaluating a single alternative. Output analysis also involves comparing the results from two or more experiments and selecting the "best" alternative.

Implementation. The final step in a simulation study consists of two activities result presentation and implementation. The most common definition of implementation is when the recommendations and suggestions from the simulation study are applied in the real world. Pidd (2004) calls this a tangible product of simulation. This is also the type of implementation that most reviews would look for in a survey of simulation applications. Implementation might not occur directly after a simulation project, and often the results from the simulation are only one of many sources of information that forms the basis of a decision. But Pidd (2004) also talks about an intangible product - improved knowledge and insight, that can be generated throughout the simulation study. It is often hard to evaluate how such improved knowledge and insight is later on translated in changes in system or people's behaviour, which makes the process of assessing the value of the simulation study even more difficult.

Pidd (2004) further distinguishes between the process and the content of a simulation study, and he also separates problem solving from project management. The process of the simulation study concerns the way it is planned, conducted and completed, while content concerns knowledge related to the problem domain as well as simulation skills. Simulation modelling is often seen as a problem-solving approach. However, in practice it may not be enough just to solve the problem technically, it has also to be managed, or handled organizationally. An interesting question emerges here, i.e. how should one evaluate a simulation project - by its process, by content or by outcome, where outcome is the product of both process and content. Pidd (2004) suggests that it is the impact on the organization by which a simulation project will most likely be judged, and not by the technical criteria. Therefore it becomes important for the simulation analyst to manage process and content, problems and projects - all simultaneously. In a similar manner, Robinson (2002) describes the quality of simulation as a relationship between process quality, content quality and outcome quality. The relative importance of each of the three concepts may vary from project to project, but some empirical findings by Robinson (2002) indicate that process quality may be substantially more important than content quality in cases where simulation is seen as a process of social change. 
The primary goal in such cases is problem solving, as opposed to constructing an accurate representation of the real system. These cases are also characterized by a short project duration and a high level of customer involvement (Robinson, 2002).

The detailed steps described above can be summarized using the four phase model described by Mitroff et al. (1974): conceptualization, modelling, model solving and implementation (see Figure 1). During the conceptualization phase researchers study the real system and make decisions about what is included in the model (model scope) and which simplifications can be made without jeopardizing the model's usefulness or validity (level of detail). The result of the conceptualization is a conceptual model which describes the modeller's understanding of the problem situation and the possible ways to solve it. During the modelling phase the simulation model (scientific model in Figure 1) is built in the computer and the researcher verifies that it behaves as expected. Validation ensures that the scientific model is an accurate representation of the reality. The model solving phase involves conducting experiments with the simulation model in order to find solutions to the real world problem. Finally, model results are implemented. According to Mitroff et al. (1974) implementation is difficult because it requires a completely different set of skills compared to those needed for modelling and model solving. It requires cooperation between managers and scientists. Mitroff et al. (1974) also point out that successful implementation depends on all steps in Figure 1, not just the step linking the solution and reality.

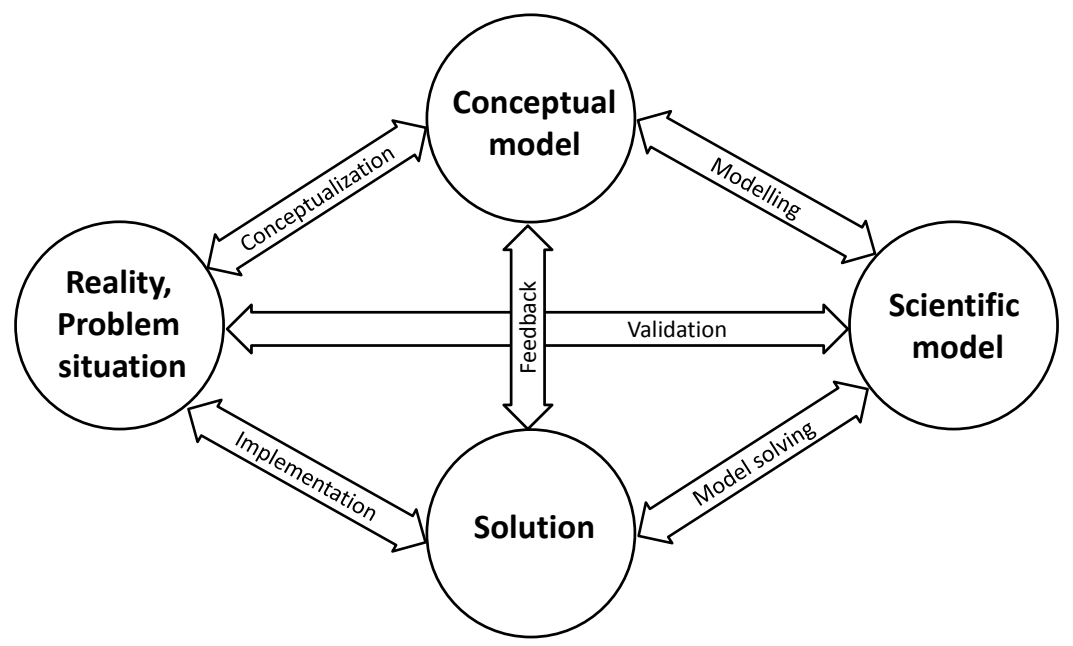

Figure 1. Problem solving using operational research methods (based on Mitroff et al. 1974)

Depending on the type of research, a study can follow the whole cycle or only parts of it. Bertrand and Fransoo (2002) mean that theoretical (axiomatic) research would 
be primarily concerned with modelling and the model solving phases, while empirical research would either take the "conceptualization-modelling-validation" route (empirical descriptive research) or the whole cycle including all four phases (empirical normative research). For operational research to become more effective, there is a need to develop and study models that are closer to real problem situation (Bertrand \& Fransoo, 2002).

If the goal is to increase the actual use of discrete-event simulation, then it follows from the discussion above that simulation methodology and methodological development should be viewed in a broad sense, i.e. not just concerning the technical content but also the process of conducting the simulation study. The starting and the ending point of the simulation study should be a real problem situation, and successful implementation will require more than just technical skills from the operational research scientist. The four phase model by Mitroff et al. (1974) is used in this thesis to position the papers' contribution to simulation methodology, covering the different phases of the empirical research cycle. 


\section{SIMULATION IN HEALTH CARE}

Simulation modelling in health care is not new and applications have existed since the early days of operational research and simulation. There have been a number of literature surveys on simulation modelling in health care (e.g. Wilson, 1981; Jun et al., 1999; Fone et al., 2003; Brailsford et al., 2009; Gunal \& Pidd, 2010; Mielczarek \& Uziałko-Mydlikowska, 2012) that cover many aspects of health care simulation. The details of these surveys provide the reader with interesting examples of the multitude of simulation applications in health care. Brailsford (2007) classifies health care models in three groups: 1) models of the human body (including biological, pharmacological and physiological models), 2) operational or tactical models that model flows of individual patients, and 3) strategic, system-wide models. Applications of discrete-event simulation to hospital resource planning, which is the focus of this thesis, belong to the second group of models in the classification above.

Health care simulation is different from simulation in production or logistics primarily because it is a service system and as such involves people (patients and staff) to a much higher degree. In a survey among simulation practitioners Tako and Robinson (2015) discovered also a number of other differences between simulation in health care and other sectors. Among these differences were more complex systems with less evident structure and messier problems, difficulties in collecting and accessing data, difficulties in developing generic models and ensuring implementation.

Low rates of implementation is a problem that has plagued health care simulation for decades. In a survey published in the early 1980s (Wilson, 1981), a long time before simulation became widely available through powerful personal computers and graphical user interfaces, only 16 out of 200 simulation projects were found to be successful in terms of implementation of study results. According to this survey the implementation can be judged as successful using several criteria:

- recommendations from the simulation study are actually carried out;

- accuracy of the model predictions compared to effects observed in real system after implementation;

- magnitude of observed effects, which can be quantified as financial savings. 
Few of the implemented projects (7 out of 16) reached the follow-up stage and three were able to calculate the financial savings. Wilson suggests that chances of implementation increase if there is a real decision-making situation, if the decision makers are actively involved in the project, data is available or is possible to collect in required amounts and quality. Wilson also concludes that health care seems to be a difficult application area for implementing operational research studies.

In a later survey by Jun et al. (1999), the focus was on discrete-event simulation applied to health care clinics with many examples of simulation models used for patient scheduling and routing as well as resource (room, bed, staff) scheduling and allocation. The survey found very few models of complex integrated systems (compare to network logistics approach (Vissers \& Beech; 2005b), discussed previously) as well as very few visually oriented models.

In a systematic review of actual use and value of simulation in health care by Fone et al. (2003), the conclusions were mainly the same as in previous surveys - a wide range of applications, including hospital organization, infectious diseases and screening but very few studies that allow to assess the value of simulation due to missing reports on implementation:

"Despite the increasing numbers of quality papers published in medical or health services research journals we were unable to reach any conclusions on the value of modelling in bealth care because the evidence of implementation was so scant." (Fone et al., 2003, p.333)

In a more recent review Brailsford et al. (2009) state that not much has changed since Wilson's study:

"Overall levels of implementation are depressingly low and suggest that little has changed since previous review articles.” (Brailsford et al., 2009, p.137)

This review reports also on the geographical distribution of documented simulation and modelling applications in health care and concludes that the majority of published studies are concentrated to North America and Europe, with USA and UK dominating the publication arena. Also, the majority of papers are published after 1990 (Brailsford et al., 2009).

A review by Gunal and Pidd (2010) finds that most papers are too specific, solving specific problems in individual units (compare to the unit logistics approach (Vissers \& Beech; 2005b), discussed previously) and are difficult to generalize from. Also, they find that model reuse is very low, which might be justified by the fact 
that sometimes the very process of building a model gives a significant contribution to knowledge gained in a simulation study.

Reflecting on the reasons for the low number of implemented studies Brailsford (2005) suggests several potential barriers to simulation implementation in health care: organizational culture in health care, high costs for developing models, poor quality data, academics willing to publish the results too quickly and a demand for specific models for each particular unit. It seems reasonable to assume that generic models would lead to higher implementation rates, although Fletcher and Worthington (2009) found no clear difference in implementation rates of generic and specific models.

Data problems are not unique to simulation - in a survey by Langabeer and Worthington (2010) more than 90\% of respondents mentioned inadequacy of information systems as the main problem when using operational research methods in health care. Harper and Pitt (2004) describe a number of challenges for the modeller in health care, including data issues, diversity among health care providers (which hinders development and use of generic models) and mistrust towards operational research models.

Brailsford et al. (2013) studied adoption of a simulation modelling tool among NHS providers and concluded that most common barriers for adoption were lack of time, lack of senior management support, lack of trained analyst capability, and data and IT issues.

It must be noted here that not all models are meant to be implemented. If the purpose of modelling is to learn, generate discussion or simply communicate ideas then "implementation" in the sense defined by Wilson (1981) is simply not possible. Some operational research methods do not require a "client" and therefore have lower proportion of implemented studies. Brailsford et al. (2009) compare low rates of implementation in studies using statistical methods to high rates in studies using qualitative methods, which almost all require a client to interact with. Simulation can be used both with or without a client, therefore a mix of implemented and not implemented studies is reasonable.

When compared to other application areas, simulation in health care appears both having less visibility and a poor success rate, although the situation is not perfect in other areas either. In industry, a survey of simulation users in Sweden (Eriksson, 2005) showed that $47 \%$ of the projects were judged as successful and $33 \%$ delivered answers that only confirmed what was already known. In a survey comparing 
simulation use in health care and defence sectors (Naseer et al., 2009) a much lower stakeholder engagement was found in health care (7.8\% compared to $38.5 \%)$ which can explain the low rates of implementing simulation outcomes. According to the study, possible reasons for this are organizational structure, low level of competition, training culture on the systems management level and restrictions in data usage (Naseer et al., 2009). Royston (2009) states that operational research is not very visible to managers and clinicians in the $\mathrm{UK}$ and that it is partly related to lack of implementation.

From all of the above the list of challenges for simulation in health care can be summarized as follows:

- Non-existent and poor quality data

- Too few models that use chain logistics or network logistics approach

- Lack of generic, conceptual models of health care sub-systems

- Low visibility among problem owners regarding both the method (simulation) and problem area (resource planning and its implications)

- Too few implemented studies

In order to move towards increased use of simulation in health care this thesis addresses some of the issues and challenges discussed above. Data quality and obstacles for developing health care chain and network models are addressed in paper II, generic model development is addressed in paper IV, low visibility among problem owners is addressed by work described in papers I, III and IV, and implementation problem in particular is addressed in paper $\mathrm{V}$. 


\section{RESEARCH CONTRIBUTIONS}

The overall aim of this thesis is to contribute to an increased use of discrete-event simulation in hospital resource planning. In order to achieve this, it is worthwhile to take a second look at the methodological cycle by Mitroff et al. (1974), presented in Figure 1, Chapter 3. From the discussion in previous chapters it is clear that the weakest link in the cycle is implementation, but to ensure a successful implementation the whole cycle matters. The goal of this thesis is to contribute with methodological developments in health care simulation by studying the needs and requirements for simulation applications in hospital resource planning, by investigating model building itself and by identifying which factors facilitate the implementation of simulation results. The five papers included in this thesis cover different parts of the methodology cycle, as illustrated in Figure 2.

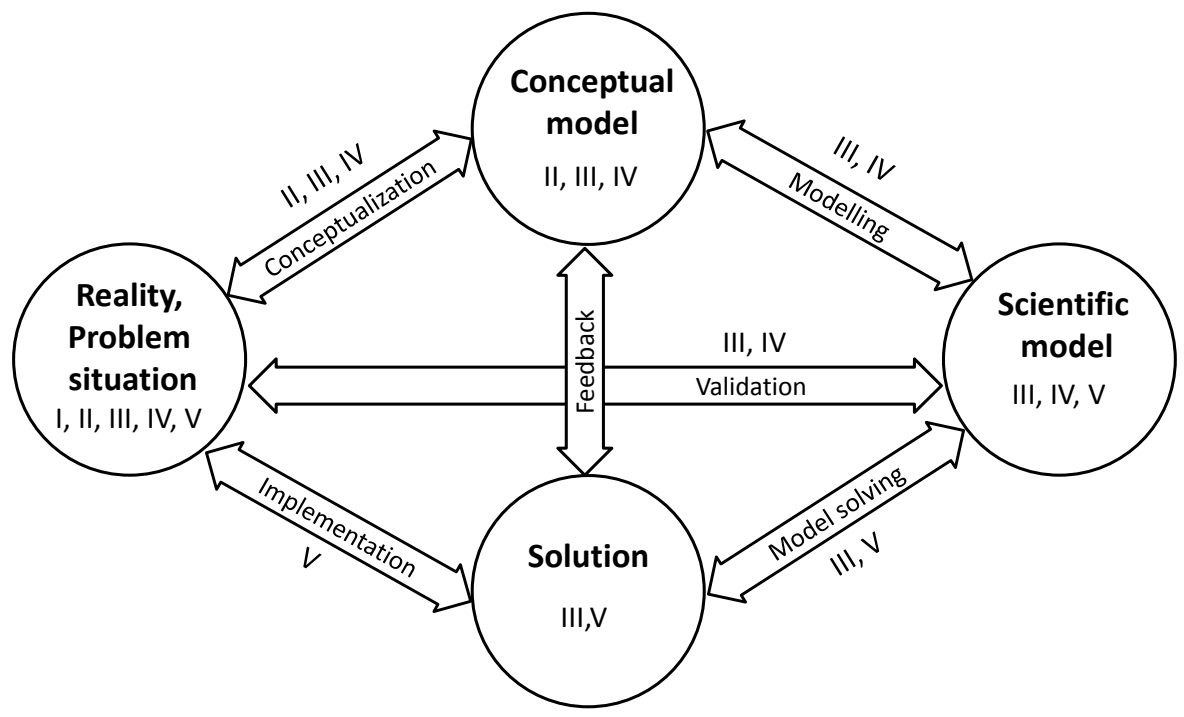

Figure 2. Methodological positioning of the five papers (I, II, III, IV, and V) included in this thesis.

All five papers have their starting point or endpoint in the real problem situation. While Paper I remains in that circle, the focus of Paper II is on the reality and the conceptualization link. Paper III focuses on conceptualization, modelling, 
validation and model solving activities. Paper IV covers conceptualization, modelling and validation. Finally, Paper V focuses on the implementation.

\section{DELIMITATIONS}

There are several ways to make simulation modelling more accessible in health care. This thesis only considers the improvement of the simulation methodology. Other directions of research could, for example, include explicitly working for decreasing the cost of simulation studies or increasing awareness through better education. Yet another approach would be to study how decision support tools like simulation are adopted and used by health care organizations.

Planning in health care can be further broken down in material planning, staff planning, facilities and equipment planning. The thesis takes an aggregated view towards capacity planning using hospital beds or operating room block time as a primary key for allocating capacity. Detailed material planning or staff scheduling is not considered in this thesis.

The research in this thesis focuses heavily on a subgroup of hospital resources operating rooms and intensive care units. The results and lessons learned may therefore not be entirely transferrable to other hospital units.

\section{CONTRIBUTIONS}

The work on the five papers has resulted in contributions that fall in the research area formed by the intersection of three subject areas - simulation, health care and resource planning. The contributions are outlined and shortly discussed below.

In order to establish the relevance and need for better planning of hospital resources, the impact of high resource utilization in hospital wards is studied, and the thesis makes following contributions:

- It shows that high resource utilization in an intensive care unit may have adverse effects on patient outcomes (Paper I).

- It shows how the usual performance measures in simulation such as resource utilization can be linked to patient outcomes (Paper I).

The literature reviews mentioned in Chapter 4 show that there are many examples of simulation applications in hospitals and its departments, but nevertheless it is claimed that health care is a "difficult" application area for simulation. By 
investigating the prerequisites and possibilities for development of simulation models, as well as by development and testing of both specific and generic models this thesis makes the following contributions:

- It demonstrates how simulation modelling can become a valuable tool for planning in a hospital operating department (Papers III and V).

- It shows how to design and validate a generic model for the capacity planning of an intensive care unit (Paper IV).

- It shows that patient flows that span over multiple hospital units are currently not very well suited for simulation in terms of data quality and availability, well defined processes and degree of decision logic formalization (Paper II).

This thesis also makes a number of contributions to the technical aspects of simulation methodology in health care which helps other researchers and practitioners when facing similar modelling challenges:

- It shows how capacity utilization can be defined across multiple hospitals and health care units in the absence of exact data on current operational capacity (Papers I and IV).

- It shows how a technique of reusing a part of the simulation model logic twice (model within a model) can be used to implement a rather complicated surgery planning logic (Paper III).

- It demonstrates the importance of proper modelling of dependencies, in particular how the admission rate to a hospital unit can be dependent on current occupancy (Paper IV).

The research also aims to shed some light to why there are so few documented implementations and what is required in order to make simulation more widely adopted. The final contribution of the thesis is therefore as follows:

- It identifies factors that can contribute to successful implementation of simulation results in health care (Paper V). 


\section{SUMMARY OF THE PAPERS}

This thesis contains five papers. The first paper examines the need for better resource planning by analysing how intensive care unit occupancy affects patient outcomes. The second paper investigates the requirements for effective application of discrete-event simulation in terms of well-defined processes and data availability. The third paper describes simulation model building and use for tactical capacity planning in hospital's operating department. The fourth paper describes the development and validation of a generic intensive care unit model which can be used for capacity dimensioning both on strategic and tactical level. The fifth paper proposes a list of factors that can facilitate implementation of simulation results in health care organizations. In this chapter all five papers are briefly described including authorship statement and publication history.

\section{Paper I:}

Does high intensive care unit occupancy have adverse effects on patient outcomes? An observational multicentre study of the relationship between occupancy and mortality.

Proper sizing of intensive care units (ICU) is extremely important since early admission and treatment in ICU is crucial for a critically ill patient. On the other hand ICU beds are some of the most expensive hospital resources, and aiming for high bed occupancy is in conflict with the desire to always have a free bed available for a critically ill patient. The objective of the study was to investigate if high occupancy levels in ICU have any adverse effects on patient outcomes.

The paper is a retrospective, observational multi-centre study where ICU admissions to 23 Swedish county hospitals from January 2009 to December 2014 were analysed in order to determine the effect of unit occupancy on patient outcomes. Patient characteristics, admission time and reason, length of stay (LOS) in the ICU were complemented with occupancy levels at each ICU at the moment of admission and discharge of each patient, along with the average occupancy during patient's entire stay at the ICU. Survival after discharge from ICU (up to 30 days) was analysed using Cox proportional hazards regression model, adjusting for patient's estimated mortality risk. 
The most central result of the study was that patients treated during high occupancy levels had an increased risk of death compared to patients treated during low-tomedium occupancy. High ICU occupancy was associated with shorter length of stay, increased proportion of night-time discharges and increased risk-adjusted mortality. This suggests that inadequately sized ICUs may have adverse effects on patient outcomes.

Paper I is co-authored with Martin Holmberg and Sten Walther. The author of this thesis was involved in research design, carried out data processing and analysis and drafted the final manuscript.

Paper I is a working paper.

Parts of the work were presented at

- 26th Annual Congress of the European Society of Intensive Care Medicine, Paris, France, 5-9 October 2013.

\section{Paper II:}

\section{A Modern Process Perspective, Process Mapping, and Simulation in Health Care. Opportunities and IT Infrastructural Needs}

Paper II investigated the current stage of digitization and process orientation in hospital care as a prerequisite for efficient process simulation and analysis. The underlying hypothesis is that with an increased level of digitization, i.e. with more and more information and data available in digital form, and with a move from functionally oriented to process oriented organizations that focus on patient flows, it should be easier to overcome some of the barriers for implementing simulation modelling and analysis in health care organizations. The increased level of digitization should simplify the data collection and analysis which is one of the most problematic steps in health care simulation. Increased process orientation in turn should lead to easier modelling of the whole patient flow across boundaries of functional units and departments.

The main objective of the paper was to investigate if the IT infrastructure is supporting the process oriented organization that the examined hospital claims that it has. Furthermore, the general conditions for applying discrete-event simulation were considered. 
The empirical case for the paper was the flow of emergency patients from the emergency department through the radiology department and back to the emergency department at a moderately large university hospital. One of the reasons for investigating this particular patient flow in terms of resources and time spent during different activities, was that the hospital had set a goal that $80 \%$ of all patients should leave the emergency department within four hours. The process model was developed together with the key actors at the hospital - nurses, physicians, administrative personnel, IT staff, and management. Historical data related to the process model was extracted from the hospital information systems and complemented with semi-structured qualitative interviews with health care professionals, on-site observations and secondary data sources.

Process mapping and subsequent data analysis revealed a process that was not very well defined and measured. Analysis also uncovered disparate information systems storing incompatible and fragmented data. The main conclusion form the study is that the current degree of process orientation and the current IT infrastructure is not enabling efficient use of quantitative process analysis and management tools such as simulation.

Paper II is co-authored with Pontus Fryk and both authors have participated in data collection, analysis and drafting of the manuscript.

Paper II is published in

- Proceedings of 2010 IEEE Workshop on Health Care Management (WHCM), Venice, Italy, Feb 18-20 2010 (Fryk \& Steins, 2010).

An earlier version of the paper is published in P. Fryk's Ph.D. dissertation

- "Modern Perspectives on the Digital Economy. With Insights from the Health Care Sector" (Fryk, 2009).

\section{Paper III:}

\section{Increasing Utilization in a Hospital Operating Department Using Simulation Modeling}

Paper III describes the development and use of a simulation model for efficient resource allocation and patient flow in a hospital operating department. Operating rooms are an expensive hospital resource, both when utilized and when idle. Planning the operating rooms is difficult due to several factors: uncertainty in 
surgery times, many stakeholders involved, and dependency on other activities scheduled for both patients and hospital resources. The planning problem is therefore complex and hard to analyse without support of tools such as discreteevent simulation.

The goal in the study was to identify problems in the patient flow and to try different alternatives for allocation of operating room capacity in order to increase the utilization of operating room resources. A secondary goal was also to investigate the possibilities of using simulation modelling in this kind of environment.

During the work several models were built with an increased level of complexity. The data required to drive the model was extracted from the operating department's information system and complemented with a number of interviews. The process depicted in the model included pre-operative care, all operating rooms and postoperative care carried out in the operating department. It also included logic for planning daily operation schedules, prioritizing and allocating both elective and emergency cases to available operating rooms. Each version of the simulation model was validated by examining and evaluating critical assumptions and by comparing model results against historical data. The operating council, consisting of representatives from the operating department and all operating specialties, was involved in model development, formulation of experimental alternatives and evaluation of the results.

The final model was used to evaluate four different proposed changes to operating room time allocation. The first experiment tested a minor reallocation of operating room block time to achieve a better fit to actual demand, the second experiment was based on a prospective scenario where one of the operating specialties would move most of their procedures out of the operating department, the third experiment tested mixing inpatient and outpatient surgery in all rooms, and the fourth experiment tested the setup of double six-hour shifts in every operating room. The results showed that a more equal resource allocation is possible to achieve in all four tested alternatives. Even though the model development was rather time consuming and required large amounts of good quality data, the overall experience with simulation at the operating department was positive - it was easy to understand, test and visualize proposed solutions in a virtual environment. The model development itself generated new insights and the study helped everyone to get the same view of the process. 
Paper III is co-authored with Fredrik Persson and Martin Holmer. The author of this thesis carried out data collection, simulation modelling and experimentation, and drafted the manuscript.

Paper III is published in

- Simulation (Transactions of The Society for Modeling and Simulation International), August 2010, vol. 86, no. 8-9, pp 463-480 (Steins et al., 2010).

Parts of the work were presented at

- 29th Congress of the Scandinavian Society of Anaesthesia and Intensive Care Medicine, SSAI 2007, Gothenburg, Sweden, September 5-8 2007.

\section{Paper IV:}

A generic simulation model for planning critical care resource requirements

Intensive care is one of the critical elements in the hospital since resource shortage here can result in dire consequences for the patients as well as it can act as a bottleneck in patient flows involving emergency department and operating rooms. It is also one of the most expensive hospital care forms. Therefore dimensioning of intensive care resources should be done accurately and taking into account the variability in the patient volumes and lengths of stay. The goal of this study was to develop a generic, simulation-based ICU capacity planning tool that could accurately estimate occupancy and the proportion of admissions that were admitted immediately on arrival (coverage) in multiple units.

Four ICUs in different hospitals were selected and data about patient visits and resource capacities was extracted from the database. The model represented a flow of patients arriving at an ICU and occupying a bed for a random length of stay. The simulation model was calibrated in several iterations with increased complexity in each new version. This was done to identify important system-wide and patientrelated characteristics that are necessary to include in the model in order to be able to represent the reality with sufficient accuracy when compared to historical data from several different ICUs. Predictive ability of the calibrated model was tested using real-life data in two cases of capacity change that had occurred in two of the ICUs studied. 
The results from the validation and calibration process indicated that some of the modelling approaches described in literature and used in earlier model versions cannot replicate the actual behaviour observed in all four ICUs. It is important to identify patient groups for different admission priorities, to account for overcrowding in the model logic, and to discover and properly model dependencies in the input data. The research demonstrated that it is possible to develop a generic ICU simulation model that could realistically describe the performance of different real ICUs in terms of occupancy, coverage and transfers.

Paper IV is co-authored with Sten Walther. The author of this thesis carried out data analysis, simulation modelling and experimentation, and drafted the manuscript.

Paper IV is published in

- Anaesthesia, November 2013, vol. 68, iss. 11, pp 1148-1155 (Steins \& Walther, 2013).

Parts of the work were presented at

- 31st Congress of the Scandinavian Society of Anaesthesia and Intensive Care Medicine, SSAI 2011, Bergen, Norway, June 15-17 2011.

\section{Paper V:}

Identifying Factors for Successful Implementation of Simulation Modeling in Healthcare

A number of academic literature surveys have shown that only a small fraction of published health care simulation studies are actually implemented. Paper V describes a successful simulation study in operating room planning at a Swedish regional hospital where simulation has been used in a project consisting of several different sub-projects over a time period of more than six years. The goal of this paper was to identify factors that can contribute to successful implementation of simulation results in health care. Given a list of potential enablers and obstacles for implementation which have been summarized and reported in the literature on the one hand, and the successful simulation project on the other hand, it is possible to identify which factors that facilitate implementation of simulation results in health care. 
The three most important factors that contributed to implementation in this case were: the timing of simulation study to support a critical decision, advantageous cost benefit ratio of the implementation and thorough model validation. Other contributing factors included high degree of staff involvement, availability of good quality data, as well as proper incentives to improve the system. Findings of this study can help in establishing the prerequisites for successful implementation in other cases.

Paper V is co-authored with Fredrik Persson. The author of this thesis carried out data collection, simulation modelling and experimentation as well as drafted the manuscript.

Paper $\mathrm{V}$ is published in

- International Journal of Privacy and Health Information Management, 3(1), JanuaryJune 2015, pp 1-19 (Steins \& Persson, 2015).

Parts of the work were presented at

- 2013 International Workshop on Innovative Simulation for Health Care, Athens, Greece, September 2013. 


\section{FUTURE RESEARCH}

To further improve the simulation methodology applied to hospital resource planning, future research could be carried out in several directions.

First, the effects of high resource utilization should be studied further, including better measurements of actual staff workload and operational capacity. Also, the factors leading to overcrowding in hospital units (emergency department, intensive care unit) should be studied further. Further analysis could be used to define target occupancy levels and to discover the optimal capacity of hospital resources.

Second, better models for predicting surgery durations and length of stay in hospital units should be developed in order to improve resource planning, as these are some of the most uncertain but nonetheless important factors influencing the accuracy of planning.

Third, work on developing models that encompass entire patient flows should also be continued. This can be accomplished, for instance, by studying how information that is required to build these models could be captured and formalized easier than it is possible today given the current state of information systems and process orientation in many hospitals.

Fourth, the ICU capacity planning model could be elaborated more to include workload as a measure of resource need (instead of beds), which is important for planning purposes. The generic model should also be made available for tests in real life situations to predict occupancy levels and coverage, for instance, in cases where structural changes are made in hospitals.

Fifth, the health care planning process itself could be studied more thoroughly, covering all hierarchical levels of planning and investigating the best possible fit between the supporting tools, such as simulation, and the activities in hospital resource planning.

Sixth, the work on simulation supported surgery planning system could be continued by developing requirements for hospital production planning systems, supported by statistical and operational research methods. 


\section{REFERENCES}

Balci, O. (1998). Verification, validation, and testing. In Banks, J. (ed.) Handbook of Simulation: Principles, Methodology, Advances, Applications, and Practice (pp. 335393). New York: Wiley.

Banks, J., Carson, J. S., Nelson, B. L., \& Nicol, D. M. (2010). Discrete-Event System Simulation (5th ed.). New Jersey: Pearson Education.

Bertrand, J. W. M., \& Fransoo, J. C. (2002). Operations management research methodologies using quantitative modeling. International Journal of Operations \& Production Management, 22(2), 241-264.

Björnberg, A. (2017). Euro Health Consumer Index 2016. Health Consumer Powerhouse.

Brailsford, S. (2005). Overcoming the barriers to implementation of operations research simulation models in healthcare. Clinical \& Investigative Medicine, 28(6), 312-315.

Brailsford, S. (2007). Tutorial: Advances and challenges in healthcare simulation modeling. Proceedings of the 2007 Winter Simulation Conference, Washington D.C., USA, December 9-12 2007, 1436-1448.

Brailsford, S., Bolt, T., Bucci, G., Chaussalet, T., Connell, N., Harper, P., \& ... Taylor, M. (2013). Overcoming the barriers: a qualitative study of simulation adoption in the NHS. Journal Of The Operational Research Society, 64(2), 157168.

Brailsford, S., Harper, P., Patel, B., \& Pitt, M. (2009). An analysis of the academic literature on simulation and modelling in health care. Journal of Simulation, 3(3), 130-140.

Brandeau, M. L., Sainfort, F., \& Pierskalla, W. P. (2004). Health care delivery: Current problems and future challenges, in Brandeau, M. L., Sainfort, F., \& Pierskalla, W. P. (eds.), Operations Research and Health Care. A Handbook of Methods and Applications (pp. 1-14). Boston: Kluwer Academic Publishers. 
Eriksson, U. (2005). Diffusion of discrete event simulation in Swedish industry: on the way to an increased understanding. Dissertation. Göteborg : Chalmers tekniska högskola.

Fletcher, A., \& Worthington, D. (2009). What is a 'generic' hospital model?-a comparison of 'generic' and 'specific' hospital models of emergency patient flows. Health Care Management Science, 12(4), 374-391.

Fone, D., Hollinghurst, S., Temple, M., Round, A., Lester, N., Weightman, A., \& ... Palmer, S. (2003). Systematic review of the use and value of computer simulation modelling in population health and health care delivery. Journal of Public Health Medicine, 25(4), 325-335.

Fryk, P. (2009). Modern perspectives on the digital economy: with insights from the bealth care sector. Dissertation. Uppsala : Uppsala universitet.

Fryk, P., \& Steins, K. (2010). A modern process perspective, process mapping, and simulation in health care: Opportunities and IT infrastructural needs. In Proceedings of 2010 IEEE Workshop on Health Care Management (WHCM), Venice, Italy, Feb 18-20 2010 doi: 10.1109/WHCM.2010.5441276

Goldratt, E. M., \& Cox J. (2004). The Goal: A Process of Ongoing Improvement (3rd ed.). Great Barrington, MA.: North River Press.

Green, L.V. (2004). Capacity planning and management in hospitals, in Brandeau, M. L., Sainfort, F., Pierskalla, W. P. (eds.), Operations Research and Health Care. A Handbook of Methods and Applications (pp. 15-41). Boston: Kluwer Academic Publishers.

Gunal, M. M., \& Pidd, M. (2010). Discrete event simulation for performance modelling in health care: a review of the literature. Journal of Simulation, 4(1), $32-51$.

Hall, R., Belson, D., Murali, P., \& Dessouky, M. (2006). Modeling patient flows through the healthcare system, in Hall, R. (ed.) Patient Flow: Reducing Delay in Healthcare Delivery (pp.101-122). New York: Springer.

Hans, E. W., Van Houdenhoven, M., \& Hulshof, P. J. H. (2012) A framework for healthcare planning and control, in Hall, R. (ed.), Handbook of Healthcare System Scheduling. International Series in Operations Research \& Management Science, 168 (pp. 303-320). Berlin: Springer. 
Harper, P. R., \& Pitt, M. A. (2004). On the challenges of healthcare modelling and a proposed project life cycle for successful implementation. Journal of the Operational Research Society, 55(6), 657-661.

Hulshof, P. H., Kortbeek, N., Boucherie, R. J., Hans, E. W., \& Bakker, P. M. (2012). Taxonomic classification of planning decisions in health care: a structured review of the state of the art in OR/MS. Health Systems, 1(2), 129.

Jun, J. B., Jacobson, S. H., \& Swisher, J. R. (1999). Application of discrete-event simulation in health care clinics: A survey. Journal of the Operational Research Society, 50(2), 109.

Källum, L. (2008). Slutrapport Projekt 106. Landstinget i Östergötland. Retrieved from http://www.skane.se/upload/Webbplatser/Utvecklingscentrum/ dokument/Rapport\%20administrativa\%20funktioner.pdf

Kelton, W. D., Sadowski, R. P., \& Zupick, N. B. (2015). Simulation with Arena (6th ed.). New York : McGraw-Hill Education.

Kosnik, L. (2006). Breakthrough demand-capacity management strategies to improve hospital flow, safety, and satisfaction, in Hall, R. (ed.) Patient Flow: Reducing Delay in Healthcare Delivery (pp.101-122). New York: Springer.

Langabeer, J. R. II, \& Worthington, D. J. (2010). Operations research diffusion in health care management. Journal of Health Care Finance, 36(3), 73-87.

Law, M. A., \& Kelton W. D. (2000). Simulation Modeling and Analysis (3rd ed.). McGraw-Hill, Inc.

McHaney, R. (1991). Computer Simulation: a Practical Perspective. San Diego: Academic Press.

Mielczarek, B., \& Uziałko-Mydlikowska, J. (2012). Application of computer simulation modeling in the health care sector: a survey. Simulation, 88(2), 197. doi:10.1177/0037549710387802

Mitroff, I.I., Betz, F., Pondy, L.R., \& Sagasti, F. (1974). On managing science in the systems age: two schemas for the study of science as a whole systems phenomenon. Interfaces, 4(3), 46-58 
Naseer, A., Eldabi, T., \& Jahangirian, M. (2009). Cross-sector analysis of simulation methods: A survey of defense and healthcare. Transforming Government: People, Process and Policy, 3(2), 181-189.

OECD (2017a). Health expenditure and financing: Health expenditure indicators. OECD Health Statistics (database). doi: http://dx.doi.org/10.1787/data00349-en. (Accessed on 21 June 2017)

OECD (2017b). Hospital beds (indicator). doi: 10.1787/0191328e-en (Accessed on 21 June 2017)

OECD (2017c). Doctors (indicator). doi: 10.1787/4355e1ec-en (Accessed on 21 June 2017)

OECD (2017d). Nurses (indicator). doi: 10.1787/283e64de-en (Accessed on 21 June 2017)

Pidd, M. (2003). Tools for Thinking. Modelling in Management Science (2nd ed.). Chichester, England: Wiley.

Pidd, M. (2004). Computer Simulation in Management Science (5th ed.). Chichester, England: Wiley.

Roberts, S. D. (2011). Tutorial on the simulation of healthcare systems. In S. Jain, R.R. Creasey, J. Himmelspach, K.P. White, and M. Fu (Eds.), Proceedings of the 2011 Winter Simulation Conference (pp. 1403-1414). Piscataway, NJ: IEEE.

Robinson, S. (2002). General concepts of quality for discrete-event simulation. European Journal of Operational Research, 138(1), 103-117.

Robinson, S. (2004). Simulation: the Practice of Model Development and Use. Chichester: Wiley.

Royston, G. (2009). One hundred years of Operational Research in Health - UK 1948-2048. Journal of the Operational Research Society, 60, 169-179.

Sargent, R. G. (2007). Verification and validation of simulation models In Proceedings of the 2007 Winter Simulation Conference Washington, D.C., USA, December 9-12 2007, 124-137.

Steins, K., \& Persson, F. (2015). Identifying factors for successful implementation of simulation modeling in healthcare. International Journal of Privacy and Health Information Management, 3(1), 1-19. 
Steins, K., Persson, F., \& Holmer, M. (2010). Increasing utilization in a hospital operating department using simulation modeling. Simulation, 86(8-9), 463480.

Steins, K., \& Walther, S. M. (2013). A generic simulation model for planning critical care resource requirements. Anaesthesia, 68(11), 1148-1155.

Stockholms läns landsting (2009). Framtidens hälso- och sjukvård. Långtidsutredningen om sjukvården i Stockholms läns landsting 2008-2025. Stockholm: Stockholms läns landsting.

Tako, A. A., \& Robinson, S. (2015). Is simulation in health different? Journal of the Operational Research Society, 66(4), 602-614.

Vissers, J., \& Beech, R. (2005a). Introduction. In Vissers, J., \& Beech, R. (eds.) Health operations management : patient flow logistics in bealth care (pp.1-11). London: Routledge.

Vissers, J., \& Beech, R. (2005b). Health operations management. Basic concepts and approaches. In Vissers, J., \& Beech, R. (eds.) Health operations management : patient flow logistics in health care (pp.39-50). London: Routledge.

Williams, M. (2006). Hospitals and clinical facilities, processes and design for patient flow, in Hall, R. (ed.) Patient Flow: Reducing Delay in Healthcare Delivery (pp.45-78). New York: Springer

Wilson, J. C. T. (1981). Implementation of computer simulation projects in health care. Journal of the Operational Research Society, 32(9), 825-832. 


\section{Papers}

The articles associated with this thesis have been removed for copyright reasons. For more details about these see:

http://urn.kb.se/resolve? urn:nbn:se:liu:diva-139732 